\title{
Sustainable Construction Practices Challenges- A Stakeholders Perspective
}

\author{
Nokulunga Mashwama ${ }^{\mathrm{a}}$, Didi Thwala ${ }^{\mathrm{b}}$, Clinton Aigbavboa ${ }^{\mathrm{c}, *}$ \\ a,b,c Department of Construction Management and Quantity Surveying, University of Johannesburg/Johannesburg, South Africa \\ SARChI in Sustainable Construction Management and Leadership in the Built Environment, Faculty of Engineering and the Built Environment, \\ University of Johannesburg/Johannesburg, South Africa \\ \{nokulungam,Aigbavboa,didibhukut\}@uj.ac.za
}

\begin{abstract}
Sustainable construction practices not only benefits government, environment and occupants but it secure the earth for future generations to come. Thus the paper discussing sustainable construction practices challenges in the construction industry of South Africa. Structured questionnaires were distributed to different construction companies and construction professionals. From the 75 questionnaires distributed, 60 were brought back and they were all valid and usable. Findings from the survey results obtained from the chosen respondents revealed that the is a lack of training in an organization regarding sustainable construction, lack of awareness of sustainable construction practices, lack of sustainable environmental materials, changes in material prices and escalations, lack of accessible guidance, lack of technical skills, resistance to change in adoption and material scarcity. The construction industry needs to promote and create more workshops on sustainable construction practices so that more stake holders would be aware of it benefits and incentives should be provided to organization that are implementing sustainable construction. Furthermore, the implementation of construction principles can be achieved successfully if all the construction stakeholders participates from design to completion of the project with the assistance of knowledgeable project manager on sustainable construction practices. The study will contribute to the body of knowledge by increasing more awareness of SC to professionals in order to be implemented.
\end{abstract}

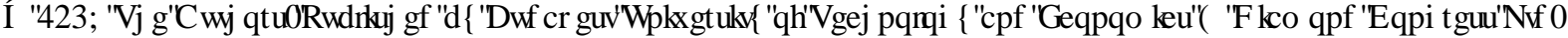

Peer-review under responsibility of the scientific committee of the Creative Construction Conference 2019.

Keywords: Challenges; Construction industry; Sustainable construction; sustainable construction practices (SCPs); construction industry; South Africa.

\section{Introduction}

According to the Green Building Council of South Africa (GBCSA)[1], sustainable construction practices are good for the environment including the occupants of the building. The main goal of sustainable construction are driven by four factors namely minimizing the impacts of construction materials on the earth, minimizing the impacts during the period when the building is occupied and making sure that the occupants have a favorable living experience, minimizing the impact of the construction when the building is being demolished [2]. Sustainable construction practices does not benefits government, environment and occupants only but it secures earth for future generations to come [3].

*Corresponding author: Author email: nokulungam@uj.ac.za 


\section{Construction Industry}

The construction industry provides us with good infrastructure [4]. However, the construction industry has a negative impact on the environment which should be taken into consideration. [5] stated that construction has a detrimental effect on the environment. Research has shown that the environmental impacts of construction activities are grave and must be minimized [6]. Infrastructure and the construction industry contribute to $60 \%$ of raw materials extracted globally [7]. Construction plays a vital role in providing infrastructure for society while having negative impact on the environment and resulting to the depletion of resources [8]. The materials used during construction contribute greatly to depletion of natural resources [9]. The processing of material requires energy and could result in waste generation, materials that are sourced elsewhere require transportation and this leads to an increased energy consumption, in a long term this will have an impact on the environment [10]. These impacts occur from the onsite phase, to operational phase of the building until the demolition phase of the building, all these cycles of a building have an impact on the environment [11].

\section{Sustainability}

Sustainability refers to three aspects which are ecological, economic and social wellbeing [8], it also governs decisions concerning building materials. The aim of sustainability is to preserve raw materials, while promoting the effective use of energy and water, and the prevention of environmental degradation caused by the infrastructures that are being constructed [12].

\section{Sustainable Construction (SC)}

[12], describes the concept of sustainable construction as the present needs being met without limiting resources for future generations. SC is concerned with making eco-efficient and environmentally friendly buildings, this can start from the decision of which transport and materials must be used that will minimize the impact on the environment [10]. Hence, there must be policies put in place for material selection [13]. According to [14] companies can save money and benefit the environment significantly by sourcing the materials locally and making few trips from the supplier. Moreover, this process can help decrease the emissions, also reduce the carbon foot print by considering environmentally friendly alternatives for materials. The principles of SC must be applied in all the construction stages until demolition as well as the management of the resultant waste [11]. Stakeholders and the client must take responsibility of their role in mitigating the problem encountered with traditional buildings and adapt to the sustainable construction practices while maximizing the economic benefits [15].

SC practices have great benefits for the environment [16], therefore, the concepts and technologies that have a function to achieve sustainability as well as yield great satisfactory results during and after construction are: Lean construction; Building information modelling (BIM); Construction ecology; Biomimicry; Value management; Ecological economics; Life cycle costing; Life cycle assessment; Industrial building system (IBS); Nanotechnology; Ecological footprint; Design for the environment.

\section{Sustainable Construction Practices Challenges}

Different countries and industries are looking for ways to reduce climate change, pollution and their impact on the world's ecology [17]. The implementation of sustainable construction has been unsuccessful in many countries due to the challenges that limit the successful implementation of SC. According to [16], the sustainable construction technologies are very expensive and costly due to the limitation of the components not being sold locally. The adoption of sustainable construction practices is client driven [18], a client with good knowledge of the benefits will encourage the use of the practices but due to lack of awareness clients do not have knowledge on some practices and decided to continue with traditional buildings. 
The challenges that limit the implementation of sustainable construction practices are: The lack of training among construction stakeholders with regards to sustainable construction; The lack of participation from the government; The lack of knowledge regarding the legal aspects and regulations; The lack of understanding of sustainable practices by the client; The lack of financial and economic risks assessments in client organization; Lack of financial incentives; Resistant to change ;Misconceptions about sustainable construction practices; Lack of sustainable materials; Lack of public awareness. According to [11], the challenges of implementing some of the SC practices such as lean construction were: administrative view point, lack of legislation, lack of specialised angle and attitudinal perspective. Lack of knowledge on sustainable practices [16]. [19] observed negative perception as a challenge, therefore, better client perception will result in better understanding and demand of sustainable construction practices. SC can be introduced during the planning and design stage, engineers must have knowledge of $\mathrm{SC}$ as to minimize the environmental impact and incorporate sustainable construction [18]. Technologies like BIM are being used for planning and quality assurance procedures using software but barriers limiting the implementation are poor management and communication, the lack of availability of software, the lack of calibration and uniform procedures and the cost to implement such technologies $[20 ; 17]$

\section{Research Methodology}

\subsection{Research area- Mpumalanga Province}

Mpumalanga means the place of the rising sun and people are drawn to the province by its magnificent scenery, fauna and flora. The province is the second smallest province in South Africa yet it has fourth -largest economy. It's situated mainly on the high plateu grasslands of the middleveld. Mpumalanga has network of excellent roads and railway connections thus making it highly accessible [21]. The province is a tourism destination and it's a home, of over 4 million people, the principal languages are siSwati and isiZulu. The province is a summer-rainfall area divided by the escarpment into the Highveld region with cold frosty winter and lowveld region with mild winters and subtropical climate. Mpumalanga is the second largest citrus producing area in South Africa and is responsible for one third of the country's export in oranges. Mpumalanga is very rich in coal reserves. The province house the country three major power stations, of which are the largest in the southern hemisphere [21]. 


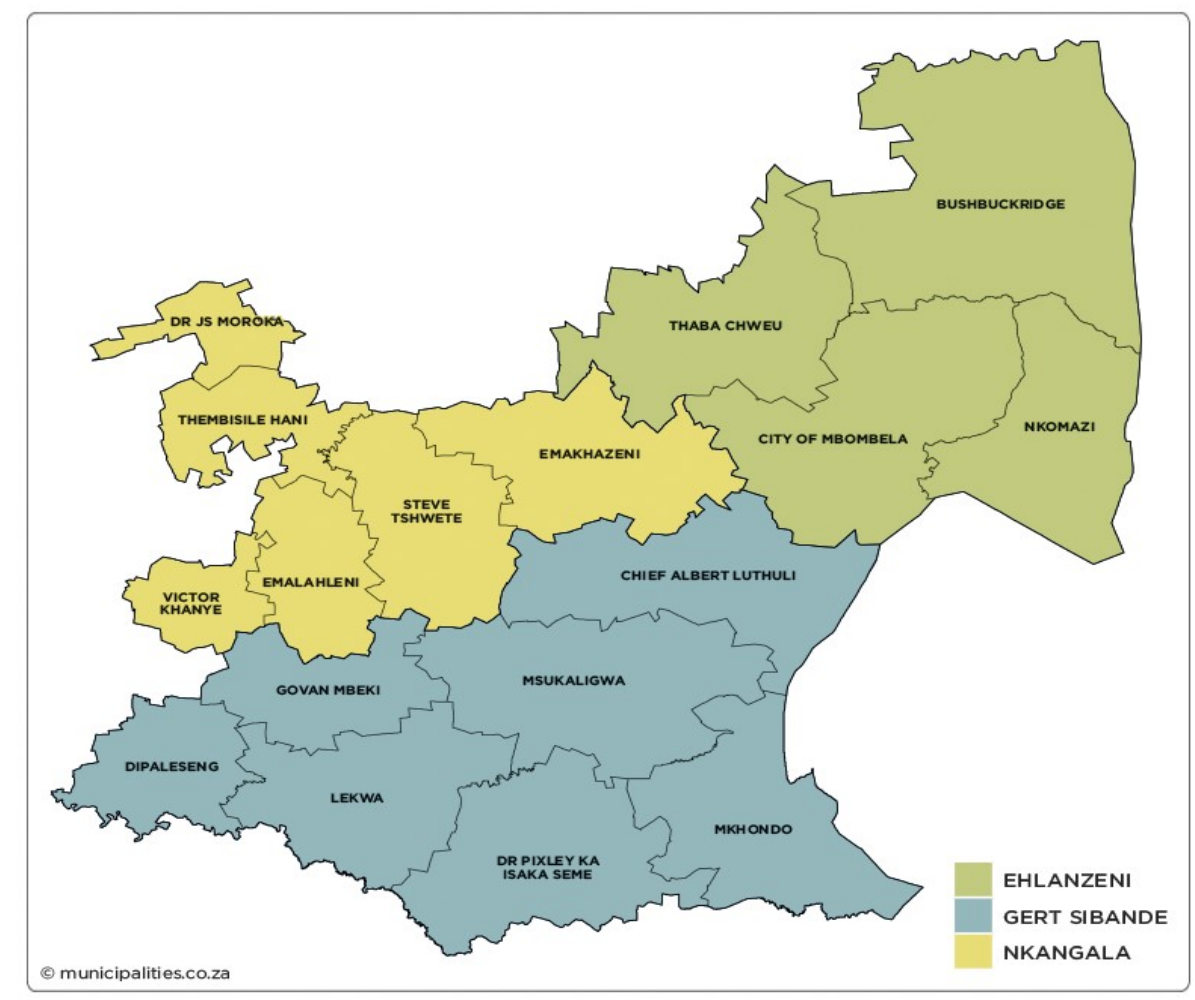

Figure 1: Mpumalanga map

\subsection{Research area- Mpumalanga Province}

Quantitative approach method was adopted to investigate a stakeholder's perspective on the challenges of implementing sustainable construction practices. The study was carried out in Mpumalanga Province of the Republic of South Africa. 75 Questionnaires were distributed and 60 were brought back which were all valid and usable. A wellstructured questionnaire was distributed to different construction companies in the Mpumalanga Province, amongst construction professionals such as civil engineers, project managers, directors, quantity surveyors, construction managers and contractors who are register on the CIDB data base. The questionnaires were sent via e-mails, some were delivered to the known construction companies by the researcher and some were distributed during site clarification meetings of contractors and consultants bidders in Mpumalanga Province. The study was conducted from reliable scholarly sources such as articles, journals, books, publications, websites and site experience on the field.

\subsection{Research area- Mpumalanga Province}

5- point linkert scale was adopted for the study which gave a wider range of possible scores and increase statistical analyses that are available to the researcher. The first linkert scale read is on agreement form as follows:

1- Strongly Disagree (SD)

2- Disagree (D)

3- $\operatorname{Neutral}(\mathrm{N})$

4- Agree (A)

5- Strongly Agree (SA)

The 5 point scales were transformed to mean item score abbreviated as (MIS). 
Nokulunga Mashwama/ Proceedings of the Creative Construction Conference (2019) 102

https://doi.org/10.3311/CCC2019-102

\subsection{Computation of the mean item score (mis)}

The computation of the mean item score (MIS) was calculated from the total of all weighted responses and then relating it to the total responses on a particular aspect. The mean item score was adopted to rank the factors from highest to lowest. The Mean Item Score (MIS) is expressed and calculated for each item as follows:

Where;

$$
\mathbf{M I S}=\frac{1 \mathrm{n} 1+2 \mathrm{n} 2+3 \mathrm{n} 3+4 \mathrm{n} 4+5 \mathrm{n} 5}{\sum \mathrm{N}}
$$

$\mathrm{n} 1=$ number of respondents for strongly disagree

$\mathrm{n} 2=$ number of respondents for disagree

$\mathrm{n} 3=$ number of respondents for neutral

$\mathrm{n} 4=$ number of respondents for agree

$\mathrm{n} 5=$ number of respondents for strongly agree

$\mathrm{N}=$ Total number of respondents

\section{Findings}

\subsection{Challenges of sustainable construction practices}

The challenges of implementing sustainable construction practices in the Mpumalanga province construction projects were identified as the lack of training in the organization which was ranked number one with (MIS=4.30 $\& \mathrm{STD}=0.941$ ); lack of awareness of sustainable construction practices was ranked second with (MIS $=4.24 \&$ $\mathrm{STD}=0.949$ ); lack of environmentally sustainable materials and change in material prices and escalation were ranked third with (MIS=4.19\& STD=0.989 and 0.993 respectively); lack of accessible guidance was ranked fourth with (MIS=3.97 \& $\mathrm{STD}=0.810$ ); lack of technical skills was ranked fifth with (MIS=3.85 \& $\mathrm{STD}=0.998$ ); resistance to change in adopting new practices was ranked sixth with (MIS=3.81 \& STD=0.761); material scarcity and delay in decision making were ranked seventh with (MIS $=3.72 \& \mathrm{STD}=0.968$ and 0.784 respectively); the price of implementing the practices and client worries profitability were ranked eight with (MIS $=3.70 \&$ STD $=0.808$ and 0.946 respectively); lack of incentives from the government was ranked nineth with (MIS=3.69 \& STD=0.838); lack of client demand was ranked tenth with (MIS=3.66 \& STD=0.893); the fragmented nature of the industry was ranked eleventh with (MIS=3.56 \& STD=0.981); lack of awareness of the benefits was ranked twelve with (MIS=3.54 \& $\mathrm{STD}=0.815$ ); potential time factor involved in implementation of new practices and lack of government support was ranked thirteen with (MIS=3.51 \& $\mathrm{STD}=0.942$ and 0.927 respectively); poor management and communication was ranked fourteen with (MIS=3.44 \& $\mathrm{STD}=0.922$ ); lack of awareness among professionals and human attitudes towards change was ranked fifteen with (MIS $=3.41 \& \mathrm{STD}=0.818 \& 0.922$ respectively).

Table 1: Sustainable Construction Practices Challenges

\begin{tabular}{|c|c|c|c|}
\hline Barriers & Mean & $\begin{array}{l}\text { Standard } \\
\text { deviation }\end{array}$ & Rank \\
\hline Lack of training in the organization & 4.30 & 0.941 & 1 \\
\hline Lack of awareness of sustainable construction practices & 4.24 & 0.949 & 2 \\
\hline Lack of environmentally sustainable materials & 4.19 & 0.989 & 3 \\
\hline Change in material prices and escalations & 4.19 & 0.993 & 3 \\
\hline Lack of accessible guidance & 3.97 & 0.810 & 4 \\
\hline Lack of technical skills & 3.85 & 0.998 & 5 \\
\hline Resistance to change in adopting new practices & 3.81 & 0.761 & 6 \\
\hline Material scarcity & 3.72 & 0.968 & 7 \\
\hline
\end{tabular}


Nokulunga Mashwama/ Proceedings of the Creative Construction Conference (2019) 102

https://doi.org/10.3311/CCC2019-102

\begin{tabular}{|l|l|l|l|}
\hline Delay in decision making & 3.72 & 0.784 & 7 \\
\hline The price of implementing the practices & 3.70 & 0.808 & 8 \\
\hline Client worries profitability & 3.70 & 0.946 & 8 \\
\hline Lack of incentives from the government & 3.69 & 0.838 & 9 \\
\hline Lack of client demand & 3.66 & 0.893 & 10 \\
\hline The fragmented nature of the industry & 3.56 & 0.981 & 11 \\
\hline Lack of awareness of the benefits & 3.54 & 0.815 & 12 \\
\hline Potential time factor involved in implementation of new practices & 3.51 & 0.942 & 13 \\
\hline Lack of government support & 3.51 & 0.927 & 13 \\
\hline Poor management and communication & 3.44 & 0.922 & 14 \\
\hline Lack of awareness among professionals & 3.41 & 0.818 & 15 \\
\hline Human attitudes towards change & 3.41 & 0.922 & 15 \\
\hline
\end{tabular}

\section{Conclusion}

Lack of training in an organisation, lack of awareness of sustainable construction practices, lack of environmental sustainable material, change in material prices and escalation, lack of accessible guidance were the top challenges of sustainable construction. Therefore, the government of South Africa is expected to conduct more workshops and training regarding SC to create more awareness among stakeholders. Since, in South Africa the adoption of sustainable construction practices is client driven its not a government mandate or a policy as yet, hence, the client must also attend such awareness training. Once the client has good knowledge of the benefits will encourage the use of the practices in their projects. Therefore, lack of awareness clients do not have knowledge on some practices and decided to continue with traditional buildings. It is recommended that contractors or companies who are already implementing the practices be encouraged through incentives or those construction material that promote sustainable construction be tax free and they must be readily available for the public to use.

\section{References}

[1] GBCSA (2013), “Green Building Council”, available at: www.gbcsa.org.za. (2013).

[2] Lark, D. (2007). The four goals of sustainable architecture .http://www.harmoniousliving.co.za/Environment/Eco-Friendly/The-Four-Goals-ofGreen-Architecture. (2007).

[3] Enshassi A. \& Kochendoerfer, B. Sustainable construction in Palestine, paper published in Proceedings of the 4th International Conference on Structural Engineering and Construction Management (ICSECM), December 2013, Kandy, Sri Lanka,(2013): pp. 46-55.

[4] N.X Mashwama, Hildah Kale, C.O Aigbavboa, Investigating the hindrances of Implementation of Occupational Health and Safety among Medium Enterprise's in the Gauteng Province of South Africa. Proceedings of the Creative Construction Conference.(2018). 906-913. https://doi.org/10.3311/CCC2018-118

[5] Li X., Zhu Y. \& Zhang Z. An LCA-based environmental impact assessment model for construction processes. Building and Environment, (2010) 45(3):766-775. https://doi.org/10.1016/j.buildenv.2009.08.010

[6] Lawrence, M., Kyakula, M. \& Batambuze, A. An Assessment of the Impact of Construction Activities on the Environment in Uganda: Acase study of Iganga Municipality. KICEM Journal of Construction Engineering and Project Management. (2012). 2(4), pp.20-24. https://doi.org/10.6106/JCEPM.2012.2.4.020

[7] Rio Merino, M., Salto-Weis, I. \& Izquierdo, P. Sustainable Constuction: construction demolition and waste reconsidered. Waste Management \& Research. (2009).Pp.118-129. https://doi.org/10.1177/0734242X09103841

[8] Gibberd, J. Sustainable Development Criteria for Built Environment Prjects in South Africa. Council for Research and Industrial Research. (2010) Vol 1. No 1.pp. 34-51.

[9] Aigbavboa, C., Oke, A. \& Edward, L. Improving Sustainable Construction Practices Through Facility Management. Sustainable Civil Infrastructures, (2017). pp.30-39. https://doi.org/10.1007/978-3-319-61645-2_3

[10] Kostavu, S. Sustainability in Construction. Bachelors Thesis. HAMK University of Applied Sciences. (2014).

[11] Ametepey, S. O. \& Aigbavboa, C. Practitioners perspectives for the implementation of sustainable construction in Ghana. Proceedings of the

DII-2014conference. (2014)

[12] Aghimien, D. O., Adegbemo, T. F., Aghimien, I. E., \& Awodele, A. O. Challenges of Sustainable Construction: A Study of Educational Buildings in Nigeria. International Journal of Built Environment and Sustainability, (2018). Vol.5 No.1, pp.33-46 https:// doi.org/10.11113/ijbes.v5.n1.244 
Nokulunga Mashwama/ Proceedings of the Creative Construction Conference (2019) 102

https://doi.org/10.3311/CCC2019-102

[13]Sinha, A. Gupta, R \& Kutnar, A. Sustainable Development and Green Building.(2014) ttps://doi.org/10.5552/drind.2013.1205

[14]Pittet D. \& Kotak T. Environmental impact of building technologies, a comparative study in Kutch District, Gujarat State, India. Paperpresented at the Ecomaterials 4, Paths towards Sustainability conference, November 2009, Bayamo, Cuba.(2009)

[15] Shubane, M. Comparative Analysis of Environmental impact assessment compliance by two developers in the northern cape province, South Africa. Postgraduate. University of South Africa.(2015)

[16]Kamar, K.A.M., Alshawi, M. \& Hamid, Z.A. Barriers to Industrialised Building Systems: The Case of Malaysia, paper proceedings in BuHu 9th International Postgraduate Research Conference (IPGRC 2009), The University of Salford, Salford, United Kingdom.(2009).

[17]Heera, L. \& Sridhar, K., "Impact of constructionmaterial on environment”, Master's Thesis, (Steel and concrete) Industrial Engineering Quality and Environmental Management, University College of Boras, (2009).

[18]Enshassi, A., Koshendoefer, B. \& Rizg, E. An Evaluation of Environmental Impacts of Construction Projects. Revista Ingeniera de construction,(2014). 29(3), pp. (234-254) http://dx.doi.org/10.4067/S0718-50732014000300002

[19]Al-Sanad, S. (2015), Awareness, Drivers, Actions, and Barriers of Sustainable Construction in Kuwait. International Conference on Sustainable Design, Engineering and Construction, Procedia Engineering,(2015). Vol.118, pp.969-983 https://doi.org/10.1016/j.proeng.2015.08.538

[20]Darko, A., and Chan, A. P. C. Critical analysis of green building research trend in construction journals. Habitat International, (2016) 57, 53-63. https://doi.org/10.1016/j.habitatint.2016.07.001

[21]Mpumalanga provincial government. https://mpumalanga.gov.za 